\title{
Surgical treatment of basal cell carcinoma: an algorithm based on the literature*
}

\author{
Flávio Barbosa Luz ${ }^{1}$ \\ Gilberto Perez Cardoso ${ }^{1}$
}

\author{
Camila Ferron ${ }^{1}$
}

DOI: http:/ / dx.doi.org/10.1590/abd1806-4841.20153304

\begin{abstract}
Although basal cell carcinoma can be effectively managed through surgical excision, the most suitable surgical margins have not yet been fully determined. Furthermore, micrographic surgery is not readily available in many places around the world. A review of the literature regarding the surgical treatment of basal cell carcinoma was conducted in order to develop an algorithm for the surgical treatment of basal cell carcinoma that could help the choice of surgical technique and safety margins, considering the major factors that affect cure rates. Through this review, it was found that surgical margins of $4 \mathrm{~mm}$ seem to be suitable for small, primary, well-defined basal cell carcinomas, although some good results can be achieved with smaller margins and the use of margin control surgical techniques. For treatment of high-risk and recurrent tumors, margins of 5-6 mm or margin control of the surgical excision is required. Previous treatment, histological subtype, site and size of the lesion should be considered in surgical planning because these factors have been proven to affect cure rates. Thus, considering these factors, the algorithm can be a useful tool, especially for places where micrographic surgery is not widely available.
\end{abstract}

Keywords: Ambulatory surgical procedures; Carcinoma, basal cell; Margin

\section{INTRODUCTION}

In general, the best treatment for basal cell carcinoma (BCC) is surgical excision. ${ }^{1,2} \mathrm{~A} 5$-year cure rate of at least $95 \%$ is considered reasonable and an acceptable goal to achieve. ${ }^{2}$ The lesion must be totally removed at the first surgical intervention, because primary BCC have higher cure rates than recurrent ones. ${ }^{3}$ Furthermore, there is a tendency that recurrent lesions become more aggressive. Consequently, the appropriate margins for complete removal of recurrent $\mathrm{BCC}$ should be almost twice as big as those for complete removal of primary BCC., ${ }^{4,5}$ Complete removal is the key for surgical treatment and it can be achieved either with safety margins or with micrographic control. Site, histological subtype, and size of the tumor are the main factors that can influence cure rates, and should be considered during surgical planning.

\section{METHODS}

A review of the literature on surgical margins for BCC was carried out. We also included articles on incomplete excision and articles which tried to identify predictive factors of recurrence. Each article was analyzed regarding surgical margins, cure rates, follow-up period, histological subtype, site and size of the tumor. Some data were grouped and presented in tables.

An algorithm was developed in order to systematize existing techniques and direct surgical treatment of BCC. Such an algorithm is not needed by Mohs micrographic surgeons, who already possess extremely effective techniques, but they are very useful in places where access to micrographic surgery is still not widely available.

Conflict of Interest: None. 
Non-surgical options, although popular and particularly useful for non-facial superficial BCC, will not be covered by this paper.

\section{RESULTS}

\section{Surgical Margins}

For small and primary BCC, Bisson et al. have advocated the use of 3-mm margins. (Table 1) ${ }^{6-11} \mathrm{How}$ ever, complete excision was achieved in only $93 \%$ of the cases. ${ }^{9}$ Kimay-Asadi et al. ${ }^{6}$ have used transoperative histological control of margins and concluded that small, nodular, well-defined BCC located on the face should be excised with 4-mm margins from the borders of the tumors. Similarly, Wolf \& Zitelli ${ }^{7}$ found that 4-mm margins totally cleared $98 \%$ of well-defined BCC smaller than $2 \mathrm{~cm}$ in diameter (but $9 \%$ of their 117 cases were larger than that). They have also found that BCCs larger than $2 \mathrm{~cm}$ in diameter tend to display more subclinical invasion than smaller ones.

Likewise, Thomas et $\mathrm{al}^{8}$ have concluded that the majority of non-melanoma skin cancers smaller than 2 $\mathrm{cm}$ in diameter should be excised with 4-mm margins, assisted by loupe magnification. However, they have also stated that well-defined tumors could be excised using 3-mm margins.

Kumar et al. ${ }^{12}$ have found an incidence of incomplete excision of $4.2 \%, 4.1 \%$, and $2.9 \%$ in 757 BCCs treated with margins of 1 to $2.5 \mathrm{~mm}, 3$ to $4 \mathrm{~mm}$, and 5 $\mathrm{mm}$ or more, respectively.

Pichardo-Velázquez et al. ${ }^{10}$ have resected 83 high-risk BCCs with transoperative histological control, according to their definition: infiltrative $>5 \mathrm{~mm}$, nodular $>10 \mathrm{~mm}$, and nose tumors. Persistent tumors were re-excised with additional margins of $3 \mathrm{~mm}$ until clearance. After 25 months without recurrence, they recommended 5-mm margins plus transoperative histological control when Mohs micrographic surgery (MMS) was not available.

\section{Incomplete Excision}

Incomplete excision rates have been reported to range from $1.54 \%$ to $28.5 \% .^{10,12-37}$ Incomplete excision was more frequent in lateral margins (Table 2). This is consistente with what is widely reported in the literature. ${ }^{12-16,18,29,38,39}$

Palmer et al. ${ }^{40}$ have re-operated incompletely excised BCCs with MMS in a mean time of 11 weeks, and found histological evidence of residual tumor in $69 \%$ of the cases. The presence of clinically visible tumors at the time of re-excision was associated with an unexpectedly large number of required stages.

\section{D efining factors on choosing surgical margins 1.Previous treatment}

The recurrence rates for primary BCC range from $0.5 \%$ to $10.1 \%$, and from $2 \%$ to $11.6 \%$ for previously treated BCC. $3,11,13,21,23,24,27,41-45$ Higher recurrence rates occur with incompletely excised $\mathrm{BCC}$ and range from $14 \%$ to $41 \%$. $17,18,23-25,32,33,39,46$

\section{Histologic subtype}

According to the data gathered in table 3 , incomplete excision of the tumor was more common in aggressive subtypes (infiltrative, mixed and sclerosing). 12,13,47,48

Through the resection of primary BCC with MMS, Salache has realized that sclerosing tumors had

TABLE 1: Tumor eradication according to various surgical margins

\begin{tabular}{lllllllll}
\hline $\begin{array}{l}\text { Surgical Margins } \\
\text { Sample Size }\end{array}$ & $\mathbf{1 m m}$ & $\mathbf{2 m m}$ & $\mathbf{3 m m}$ & $\mathbf{4 m m}$ & $\mathbf{5 m m}$ & $\mathbf{6 m m}$ & $\mathbf{8 m m}$ & $\mathbf{1 1 m m}$ \\
\hline $\mathrm{n}: 134^{13}$ & & & & & & & & \\
$\mathrm{n}: 117^{* 6}$ & $84 \%$ & $76 \%$ & $87 \%$ & & & & & \\
$\mathrm{n}: 91^{7}$ & - & $75 \%$ & $85 \%$ & $98 \%$ & - & - & - & - \\
$\mathrm{n}: 100^{8}$ & $64 \%$ & $76 \%$ & $89 \%$ & $96 \%$ & - & - & - & - \\
$\mathrm{n}: 49 \cdot 9$ & $83 \%$ & $92 \%$ & $96 \%$ & - & - & - & - & - \\
$\mathrm{n}: 862 \cdot \cdot 10$ & - & - & - & - & $61,26 \%$ & - & $91,83 \%$ & 97,95 \\
\hline
\end{tabular}

Basal Cell Carcinoma $($ BCC $)<2 \mathrm{~cm}$

- high-risk BCC

-・ primary and recurrent $\mathrm{BCC}$

TABLE 2: Grouped incomplete excision rates according to positive margins 12-16,38,39

\begin{tabular}{ccc}
\hline Positive lateral margin & Positive deep margin & Positive lateral and deep margins \\
\hline $66.19 \%(562 / 849)$ & $21.08 \%(179 / 849)$ & $9.89 \%(84 / 849)$ \\
\hline
\end{tabular}

- In 3.53\% (30/849) of cases there was no reference to which margin has been affected

- Three lesions which had simultaneously positive deep and lateral margins were included into all three groups 14 
greater subclinical extension than other tumors. ${ }^{49} \mathrm{Sim}-$ ilarly, Lang and Lee et al. have found that aggressive recurrent $\mathrm{BCC}$ had greater subclinical extensions than non-aggressive ones. ${ }^{50,51}$ Welsch et al. have found that deep invasion was more frequent in aggressive BCC, mainly in the micronodular and infiltrative types. ${ }^{52}$

Sexton et al. have found that aggressive subtypes had the highest incomplete excision rates (micronodular $18.6 \%$, infiltrative $26.5 \%$ and sclerosing $33.3 \%)$, whereas nodular and superficial BCC treated by standard surgery had high complete excision rates (93.6\% and $96.4 \%$, respectively). ${ }^{47}$

\section{Site}

The most frequent sites for incomplete excision are the nose, the ear and the area around the eyes (Table 4 ). ${ }^{12-21,38}$

\section{Size}

There is controversy whether the size affects or not $\mathrm{BCC}$ recurrence rate. However, some authors have noted that incomplete excision was more common in larger lesions. ${ }^{3,12,14,23,41,42,53,54}$

\section{G ender}

It is not well known whether gender can influence the recurrence rate of BCC. There are reports which state that BCC recurs more often in men. Silverman et al. ${ }^{3}$ have identified the male gender as an independent factor for recurrence., ${ }^{3,42,55}$ On the other hand, incomplete excision was more common in women. $12,15,19,35$

\section{DISCUSSION}

The recurrence rate is higher in incompletely excised lesions, and primary BCC recurs less often than previously treated BCC. ${ }^{3}$ Therefore, the proper use of suitable surgical margins for BCC is a key point, given that the greatest chance of cure lies in the first approach.

The identification of clinical margins is the first step to correctly apply surgical margins. Apparently, preoperative use of loupe magnification or dermoscopy may favor recognition of the margins, improv-

TABLE 3: Grouped incomplete excision rates according to histological subtype

\begin{tabular}{|c|c|c|}
\hline Histological subtype & H istological growth & \% Incomplete excision \\
\hline Infiltrative ${ }^{* * 12,13,47}$ & Aggressive & $22.42 \%(50 / 223)$ \\
\hline Mixed ${ }^{\square 12,47}$ & Aggressive & $22.08 \%(55 / 249)$ \\
\hline Sclerosing ${ }^{12,13,47}$ & Aggressive & $15.78 \%(12 / 76)$ \\
\hline Superficial *12,13,47 & Indolent & $7.56 \%(19 / 251)$ \\
\hline Nodular $12,13,47$ & Indolent & $3.18 \%(19 / 596)$ \\
\hline Grouped subtypes: ${ }^{*} 8$ superficial +7 multifocal ${ }^{13}$ & ** 29 infiltrative +1 micronodular ${ }^{12}$ & 24 infiltrative +59 micronodular ${ }^{47}$ \\
\hline
\end{tabular}

TABLE 4: Grouped incomplete excision rates according to lesion site

\begin{tabular}{|c|c|}
\hline Site & \% Incomplete excision \\
\hline Nose ${ }^{12-15,17-21,38}$ & $13.6(315 / 2301)$ \\
\hline Ears area ${ }^{12-15,17-21,38}$ & $13.2(147 / 1108)$ \\
\hline Periocular ${ }^{12-15,17-21,38}$ & $11.7(142 / 1204)$ \\
\hline Lips $12,13,18,20,21,38$ & $9.2(22 / 237)$ \\
\hline Rest of the face ${ }^{13,15,17-21}$ & $7.78(154 / 1979)$ \\
\hline Fronto-temporal area ${ }^{12-15,18-21,38}$ & $6.81(185 / 2713)$ \\
\hline Scalp ${ }^{12-15,18-21,38}$ & $6.2(29 / 465)$ \\
\hline Trunk ${ }^{12,14,15,18-21,38}$ & $5.0(69 / 1374)$ \\
\hline Members ${ }^{12,14,15-21,38}$ & $4.0(82 / 2043)$ \\
\hline Neck $12,14,15,18,19,21,38$ & $1.6(21 / 744)$ \\
\hline
\end{tabular}

ing complete excision rates..$^{8,56-58}$ Caresana and Giardini have reported a $98.5 \%$ complete excision rate of BCC excised with 2-mm margins, demarcated with the use of dermoscopy. ${ }^{59}$

\section{Surgical M argins}

By analyzing table1, it can be concluded that the use of 4-mm margins were satisfactory for primary well-defined BCCs smaller than $2 \mathrm{~cm}$ in diameter. Similar cure rates were achieved with 3-mm margins, although, occasionally, 2-mm margins may be enough. 9,12 Nevertheless, Bisson has found that margins smaller than $3 \mathrm{~mm}$ increase recurrence risk, even if histopathology is tumor-free. ${ }^{9}$ Based on that, this paper suggests excision with 3- to 5-mm margins for: any primary BCCs with indolent histology; or - small BCCs with aggressive growth outside the high-risk 
areas. For other aggressive types of BCCs, we suggest surgery with margin control (Figure 1).

There is a gap in the literature on the ideal surgical margins for excision of high-risk and recurrent BCCs. Despite the fact that micrographic control is the best choice, some authors have suggested 5-mm margins for high-risk and 6-mm margins for reccurent BCCs as still appropriate. Based on these results; this paper suggests excision with at least 6-mm margins or surgery with margin control for recurrent BCC with indolent growth in low-risk areas and intermediate-risk areas, provided that they are small. ${ }^{10,11}$ For other large tumors with indolent growth and for all aggressive recurrent BCCs, the authors suggest micrographic surgery, given that the subclinical extension of these lesions is unpredictable (Figure 2).

In general, our indications for surgical excision with controlled margins are in agreement with the AAD/ACMS/ASDSA/ASMS guidelines. ${ }^{60}$ However, this paper suggests alternative techniques when micrographic techniques are not accessible (Figures 1 and 2).

\section{D efining factors on choosing the surgical margins 1.Previous treatment}

Any comparison between recurrence rates reported in the literature should be made carefully as the studies differ on the surgical techniques and follow-up time used, on the status of the tumor and on recurrence rates after incomplete excision.

Silverman et al. ${ }^{61}$ have reported that follow-up time, status of tumor and different statistical methodologies interfered with the results. Rowe et al., ${ }^{62}$ in a systematic review, have found that the 5-year recurrence rate was at least 3.5 times greater when the follow-up time was shorter.

Classifying primary or recurrent tumors is essential for surgical planning, because primary BCCs have lower recurrence rates than previously treated BCCs and the margins necessary for complete eradication of recurrent tumors are almost twice as big as those required to eradicate primary BCCs. ${ }^{3,5,11}$ Moreover, recurrent lesions have higher risk of recurrence, greater subclinical extension and a tendency to become more aggressive than the original tumor. ${ }^{1,550,63}$

FiguRE 1: Algorithm for treatment of primary Basal Cell Carcinoma

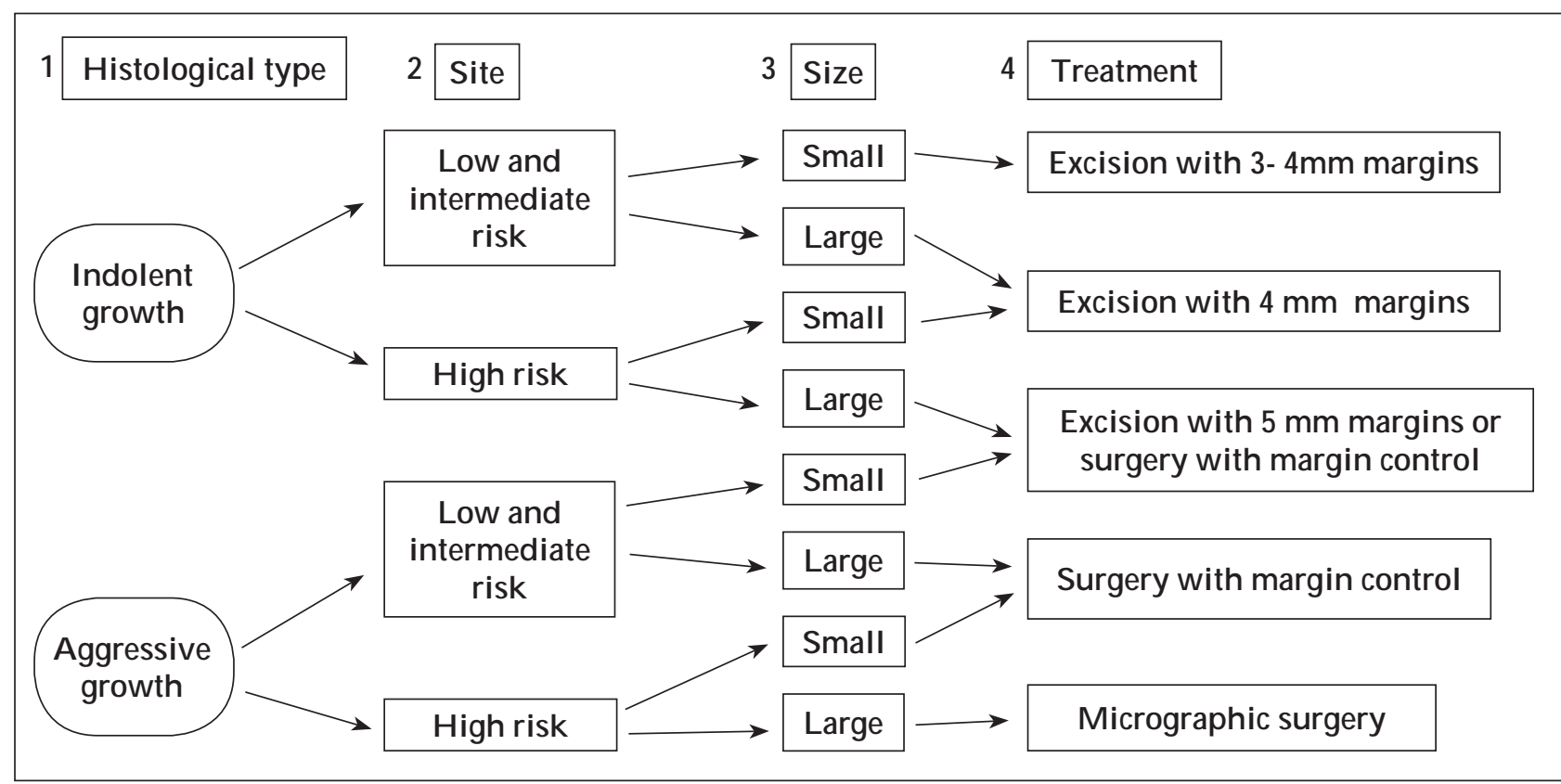

1- Aggressive: infiltrative, sclerosing and metatypical

Indolent: nodular and superficial

The authors suggest to classify the mixed (pleomorphic) subtype as aggressive for treatment purposes, even if the predominant pattern is indolent

2- Low risk: trunk and extremity

Intermediate risk: scalp, neck, forehead and cheek

High risk: centrofacial, nose, temple, periocular region, perioral and ears

3-There is no consensus on the classification of tumor size. The authors suggest to classify large lesions as lesions larger than 1cm in high-risk áreas; lesions larger than $2 \mathrm{~cm}$ in intermediate-risk áreas; and lesions larger than $4 \mathrm{~cm}$ in low-risk areas

4-The control of margins can be done by several micrographic techniques or by freezing.

Micrographic surgery can be performed using the Mohs technique, the Munich technique or the Tübingen technique. 
Figure 2: Algorithm for treatment of primary Basal Cell Carcinoma

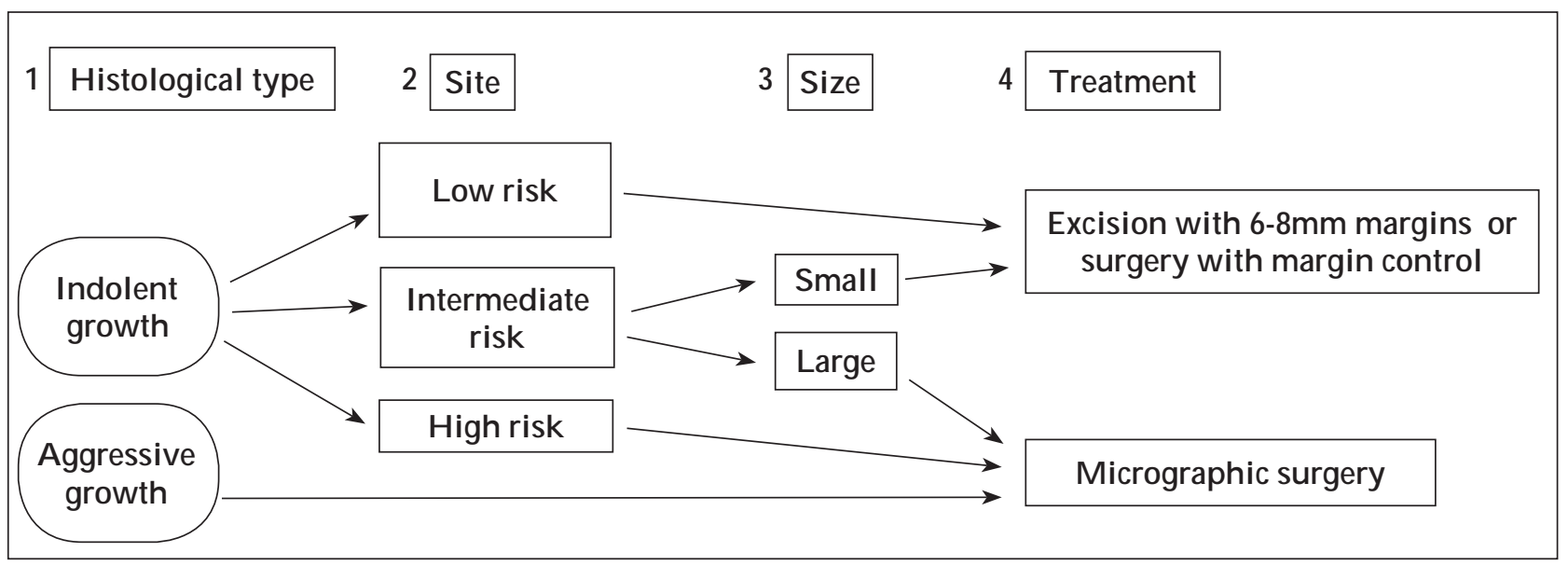

Consequently, the choice of technique must consider the previous treatment history. For primary tumors, conventional surgery with suitable margins can be applied safely to most cases (Figure 1). ${ }^{1}$ In the case of recurrent tumors, although micrographic surgery is the treatment of choice, satisfactory outcomes have been obtained with other margin control methods and/or excision with wider margins. ${ }^{11}$ Therefore, the present paper suggests at least 6-mm margins or surgical margin control, either using a micrograph or not (Figure 2).

\section{Histological subtype}

Because some histological subtypes are more associated with high rates of incomplete excision and recurrence, the analysis of histological growth pattern is a key factor to be considered when planning surgery.

In 2006, Crowson ${ }^{48}$ classified BCC as indolent (superficial and nodular) or aggressive (infiltrative, metatypical, micronodular and sclerosing). Previously, it had been shown that more aggressive histological growth was associated with increased subclinical extension, indicating that more aggressive tumors require larger surgical margins to be eradicated. ${ }^{64}$ Crowson's classification is simple and practical, therefore it was adapted and included in our algorithm. In this paper, a mixed subtype was considered aggressive because of high incomplete resection rates. Furthermore, Betti et $\mathrm{al}^{65}$ have also concluded that mixed BCC have a potential aggressive behavior. They have observed that the superficial or nodular subtype was associated with infiltrative/morpheiform types in more than $40 \%$ of cases and margin involvement was more prevalent in mixed than in single BCC.

The aggressive subtypes are clearly more likely to recur and should be treated with wider margins or histological control. In table 3, it can be seen that infiltrative and mixed patterns were mostly associated with complete excision $(22.42 \%$ and $22.08 \%$, respectively).
Sexton et al. have identified $30.1 \%$ of incomplete excision when these two patterns were associated. ${ }^{47}$

In this algorithm, superficial BCC was classified as of indolent growth and surgical approach was the only treatment that was considered. Nevertheless, Roozeboom et al. ${ }^{66}$ have discussed others therapies in a recent review. On the other hand, Mina et $\mathrm{al}^{67}$ have reviewed 158 purely superficial, primary and recurrent BCCs in the head and neck region, treated with MMS. They have found higher recurrence rates (3,7\%) and larger defect sizes than expected.

The correspondence between the histological subtype found in the biopsy and the one found in the subsequent excision ranged from $60.9 \%$ to $82 \%$ in primary BCCs, and reached $67.1 \%$ in recurrent tumors. ${ }^{52,68-}$ ${ }^{72}$ The biopsy failed to identify aggressive componentes in up to $11 \%$ of primary tumors and in $19 \%$ of recurrent tumors. ${ }^{69,72}$ This fact may be due to the frequent association between different histological types - as there are reports of up to $74 \%$ of primary mixed tumors - and to the fact that the accuracy in identifying mixed tumors is quite small (37\%) when compared to tumors of a single histological type (83\%)..$^{68,69}$ Messina et al. ${ }^{73}$ have found a correlation between the histological type predominantly found in biopsy material and the one found in the surgical specimen in $78.3 \%$ of cases. When the biopsy described the predominant and accessory types, the correlation increased $8.7 \%$, reaching $87 \%$. When BCC was classified as aggressive or non-aggressive, the correlation reached $92.7 \%$. These findings are extremely important because tumor aggressiveness will determine surgical margins. Therefore, prior biopsy is a guiding element routinely used in tumor management.

\section{Site}

Table 4 is in agreement with most reports in the literature. However, the scalp and other high-risk areas on the face have already been associated with higher 
recurrence rates. ${ }^{15-22,29,32,37,41,53,55,66}$ Based on these results, tumor site seems to influence cure rates, although this association is not significant for some authors. Following this reasoning, the recurrence rates in these highrisk areas may be related to the use of smaller safety margins and not to specific tumor characteristics.

Huang and Boyce have divided the body in low-, intermediate- and high-risk areas. ${ }^{64}$ The trunk and the extremities are low-risk areas; the cheeks, forehead, scalp and neck are intermediate-risk areas; and the central facial area, the nose, jaw, the temples, and the periocular, perioral and periauricular areas are high-risk areas.

In this review, except for the jaw and the temples, the nose, the ears and the periocular regions reached the highest rates of incomplete excision (Table 4). This classification was therefore adopted by our algorithm (Figures 1 and 2).

\section{Size}

Despite the controversial influence of tumor size on recurrence rates, Breuninger and Dietz ${ }^{5}$, similarly to Wolf and Ziteli ${ }^{7}$, have proved that there is a wide variation in subclinical extension, in terms of tumor diameter. Reinforcing this view, Cigna et al. have reported that tumors larger than $5 \mathrm{~cm}$ in diameter have poor prognosis. ${ }^{27}$

\section{REFERENCE}

1. Telfer NR, Colver GB, Morton CA; British Association of Dermatologists. Guidelines for the management of basal cell carcinoma. Br J Dermatol. 2008;159:35-48.

2. Gulleth Y, Goldberg N, Silverman RP, Gastman BR. What is the Best Surgical Margin for a Basal Cell Carcinoma: A Meta-Analysis of the Literature. Plast Reconstr Surg. 2010;126:1222-31.

3. Silverman MK, Kopf AW, Bart RS, Grin CM, Levenstein MS. Recurrence Rates of Treated Basal Cell carcinomas. Part 3: Surgical Excision. J Dermatol Surg Oncol. 1992;18:471-6.

4. Boulinguez S, Grison-Tabone C, Lamant L, Valmary S, Viraben R, Bonnetblanc $\mathrm{JM}$, et al. Histological evolution of recurrent basal cell carcinoma and therapeutic implications for incompletely excised lesions. Br J Dermatol. 2004;151:623-6.

5. Breuninger $\mathrm{H}$, Dietz K. Prediction of Subclinical Tumor Infiltration in Basal Cell Carcinoma. J Dermatol Surg Oncol. 1991;17:574-8.

6. Kimyai-Asadi A, Alam M, Goldberg LH, Peterson SR, Silapunt S, Jih MH. Efficacy of narrow-margin excision of well-demarcated primary facial basal cell carcinoma. J Am Acad Dermatol. 2005;53:464-8.

7. Wolf DJ, Zitelli JA. Surgical Margins for basal cell carcinoma. Arch Dermatol. 1987;123:340-4.

8. Thomas DJ, King AR, Peat BG. Excision margins for nonmelanotic skin cancer. Plast Reconstr Surg. 2003;112:57-63.

9. Bisson MA, Dunkin CS, Suvarna SK, Griffiths RW. Do plastic surgeons resect basal cell carcinomas too widely? A prospective study comparing surgical and histological margins. Br J Plast Surg. 2002;55:293-7.

10. Pichardo-Velázquez P, Domínguez-Cherit J, Vega-Memije Ma, Moreno-Coutiño G, Proy H. Surgical option for nonmelanoma skin cancer. Int $J$ Dermatol. 2004;43:148-50.

11. Wetzig T, Woitek M, Eichhorn K, Simon JC, Paasch U. Surgical excision of basal cell carcinoma with complete margin control: outcome at 5-years follow-up. Dermatology. 2010;220:363-9.

12. Kumar P, Watson S, Brain AN, Davenport PJ, McWilliam LJ, Banerjee SS, et al. Incomplete excision of basal cell carcinoma: a prospective multicentre audit. $\mathrm{Br} \mathrm{J}$ Plast Surg. 2002;55:616-22.
Based on these studies, tumor size was adopted as one of the elements to be considered in the algorithm (Figures 1 and 2). As most studies concerning surgical margins have included mostly smaller tumors, the optimal approach for larger tumors still lacks substantial evidence.

\section{CONCLUSION}

Despite the broad literature available on the treatment of basal cell carcinoma, there are only a few articles about surgical margins and most of them are limited to analyzing small and primary lesions. A 4-mm excision margin seems to be suitable to eradicate primary BCC lesions smaller than $2 \mathrm{~cm}$ in diameter. Nevertheless, even in these tumors histological types, lesion site and previous treatment history must be considered in surgical planning.

Surgical techniques with micrographically controlled margins are more appropriate for recurrent lesions, because conventional surgery often relies on the application of oncological radical resection with three-dimensional margins exceeding $6 \mathrm{~mm}$.

However, limited access to micrographic techniques, especially outside the USA, requires the use of alternative techniques until Mohs' micrographic surgery becomes more widely disseminated. Therefore, the algorithm shown in figures 1 and 2 may be a useful tool in guiding the surgical treatment of basal cell carcinoma. $\square$

13. Farhi D, Dupin N, Palangié A, Carlotti A, Avril MF. Incomplete Excision of Basal Cell Carcinoma: Rate and Associated Factors among 362 Consecutive Cases. Dermatol Surg. 2007;33:1207-14.

14. Kumar $\mathrm{P}$, Orton $\mathrm{Cl}$, McWilliam LJ, Watson S. Incidence of incomplete excision in surgically treated basal cell carcinoma: a retrospective clinical audit. $\mathrm{Br} \mathrm{J}$ Plast Surg. 2000;53:563-6.

15. Malik V, Goh KS, Leong S, Tan A, Downey D, O'Donovan D. Risk and outcome analysis of 1832 consecutively excised basal cell carcinoma's in a tertiary referral plastic surgery unit. J Plast Reconstr Aesthet Surg. 2010;63:2057-63.

16. Dieu T, Macleod AM. Incomplete excision of basal cell carcinomas: a retrospective audit. ANZ J Surg. 2002;72:219-21.

17. Nagore E, Grau C, Molinero J, Fortea JM. Positive margins in basal cell carcinoma: relationship to clinical features and recurrence risk. A retrospective study of 248 patients. J Eur Acad Dermatol Venereol. 2003;17:167-70.

18. Sherry KR, Reid LA, Wilmshurst AD. A five year review of basal cell carcinoma excisions. J Eur Acad Dermatol Venereol. 2003;17:167-70.

19. Hansen C, Wilkinson D, Hansen M, Soyer HP. Factors contributing to incomplete excision of nonmelanoma skin cancer by Australian general practitioners. Arch Dermatol Arch Dermatol. 2009;145:1253-60.

20. Bogdanov-Berezovsky A, Cohen AD, Glesinger R, Cagnano E, Krieger $Y$, Rosenberg L. Risk Factors for Incomplete Excision of Basal Cell Carcinomas. Acta Derm Venereol. 2004;84:44-7.

21. Goh BK, Ang P, Wu YJ, Goh CL. Characteristics of basal cell carcinoma amongst Asians in Singapore and a comparison between completely and incompletely excised tumors. Int J Dermatol. 2006;45:561-4.

22. Griffiths RW. Audit of histologically incompletely excised basal cell carcinomas: recommendations for management by re-excision. Br J Plast Surg. 1999;52:24-8.

23. Hussain M, Earley MJ. The incidence of incomplete excision in surgically treated basal cell carcinoma: a retrospective clinical audit. Ir Med J. 2003;96:18-20.

24. Foo CL, Tan SH, Tan KC. Basal cell carcinoma of the head and neck region - a fiveyear study (1984-88). Ann Acad Med Singapore. 1990;19:182-5.

25. Rippey JJ, Rippey E. Characteristics of incompletely excised basal cell carcinoma 
of the skin. Med J Aust. 1997;166:581-3.

26. Tiftikcioğlu YO, Karaaslan O, Aksoy HM, Aksoy B, Koçer U. Basal cell carcinoma in Turkey. J Dermatol. 2006;33:91-5

27. Cigna E, Tarallo M, Maruccia M, Sorvillo V, Pollastrini A, Scuderi N. Basal cell carcinoma: 10 years of experience. J Skin Cancer. 2011;2011:476362.

28. Friedman HI, Williams T, Zamora S, al-Assaad ZA. Recurrent basal cell carcinoma in margin-positive tumors. Ann Plast Surg. 1997;38:232-5.

29. Bariani RL, Nahas FX, Barbosa MV, Farah AB, Ferreira LM. Basal cell carcinoma: an updated epidemiological and therapeutically profile of an urban population. Acta Cir Bras. 2006;21:66-73

30. Schreuder F, Powell BW. Incomplete excsion of basal cell carcinomas: na audit. Clin Perform Qual Health Care. 1999;7:119-20.

31. Babaye-Nazhad S, Amirnia M, Alikhah H, Khodaeyani E, Atapour N. Safety margin in excision of basal cell carcinoma. Pak J Biol Sci. 2009;12:1408-14.

32. Santiago F, Serra D, Vieira R, Figueiredo A. Incidence and factors associated with recurrence after incomplete excision of basal cell carcinomas: a study of 90 cases. J Eur Acad Dermatol Venereol. 2010;24:1421-4.

33. Wilson AW, Howsam G, Santhanam V, Macpherson D, Grant J, Pratt CA, et at. Surgical management of incompletely excised basal cell carcinoma of the head and neck. Br J Oral Maxillofac Surg. 2004;42:311-4.

34. Pua VS1, Huilgol S, Hill D. Evaluation of the treatment of non-melanoma skin cancers by surgical excision. Australas J Dermatol. 2009:50:171-5.

35. Fleischer AB Jr, Feldman SR, Barlow JO, Zheng B, Hahn HB, Chuang TY, et al. The specialty of the treating physician affects the likehood of tumor-free resection margins for basal cell carcinoma: results from a multi-institutional retrospective study. J Am Acad Dermatol. 2001;44:224-30.

36. Asif M, Mamoon N, Ali Z, Akhtar F. Epidemiological and excision margin status of basal cell carcinoma- three years armed forces institute of pathology experience in Pakistan. Asian Pac J Cancer Prev. 2010:11:1421-3.

37. Hakverdi S, Balci DD, Dogramaci CA, Toprak S, Yaldiz M. Retrospective analysis of basal cell carcinoma. Indian J Dermatol Venereol Leprol. 2011;77:251.

38. Griffiths RW, Suvarna SK, Stone J. Basal cell carcinoma histological clearance margins: an analysis of 1539 conventionally excised tumours. Wider still and deeper? J Plast Reconstr Aesthet Surg. 2007;60:41-7.

39. Richmond JD, Davie RM. The significance of incomplete excision in patients with basal cell carcinoma. Br J Plast Surg. 1987;40:63-7.

40. Palmer VM, Wilson PR. Incompletely Excised Basal Cell Carcinoma: Residual Tumor Rates at Mohs Re-Excision. Dermatol Surg. 2013:39:706-18.

41. Bart RS, Schrager D, Kopf AW, Bromberg J, Dubin N. Scalpel excision of basal cell carcinoma. Arch Dermatol. 1978:114:739-42.

42. Rigel DS, Robins P, Friedman RJ. Predicting recurrence of basal-cell carcinomas treated by microscopically controlled excision. A recurrence index score. J Dermatol Surg Oncol. 1981;7:807-10.

43. Cataldo PA, Stoddard PB, Reed WP. Use frozen section analysis in the treatment of basal cell carcinoma. Am J Surg. 1990;159:561-3.

44. Niederhagen B, von Lindern JJ, Bergé S, Appel T, Reich RH, Krüger E. Staged operations for basal cell carcinoma of the face. $\mathrm{Br} \mathrm{J}$ Oral Maxillofac Surg. 2000;38:477-9.

45. Chow VL, Chan JY, Chan RC, Chung JH, Wei WI. Basal Cell Carcinoma of the Head and Neck Region in Ethnic Chinese. Int J Surg Oncol. 2011;2011:890908.

46. Longhi P, Serra MP, Robotti E. Incompletely excised basal cell carcinomas: our guidelines. Onco Targets Ther. 2008;1:1-4.

47. Sexton M, Jones DB, Maloney ME. Histologic pattern analysis of basal cell carcinoma. Study of a series of 1039 consecutive neoplasms. J Am Acad Dermatol. 1990;23:1118-26

48. Crowson AN. Basal cell carcinoma: biology, morphology and clinical implications. Mod Pathol. 2006;19:S127-47.

49. Salasche SJ, Amonette RA. Morpheaform basal cell epithelioma. A study of subclinical extensions series of 51 cases. J Dermatol Surg Oncol. 1981;7:387-94.

50. Lang PG Jr, Maize JC. Histologic evolution of recurrent basal cell carcinoma and treatment implications. J Am Acad Dermatol. 1986;14:186-96.

51. Lee KC, Higgins HW 2nd, Cruz AP, Dufresne RG Jr. Characteristics of Basal Cell carcinoma of the Lip Treated Using Mohs Micrographic Surgery. Dermatol Surg. 2012;38:1956-61.

52. Welsch MJ, Troiani BM, Hale L, DelTondo J, Helm KF, Clarke LE. Basal cell carcinoma characteristics as predictors of depth of invasion. J Am Acad Dermatol. 2012;67:47-53

53. Bøgelund FS, Philipsen PA, Gniadecki R. Factors affecting the recurrence rate of basal cell carcinoma. Acta Derm Venereol. 2007:87:330-4

54. Kyrgidis A, Vahtsevanos K, Tzellos TG, Xirou P, Kitikidou K, Antoniades K, et al. Clinical, histological and demographic predictors for recurrence and second primary tumours of head and neck basal cell carcinoma. A 1062 patient-cohort study from a tertiary cancer referral hospital. Eur J Dermatol. 2010;20:276-82.

55. Bumpous JM, Padhya TA, Barnett SN. Basal cell carcinoma oh the head and neck: identification of predictors of recurrence. Ear Nose Throat J. 2000;79:200-2, 204.

56. Carducci M, Bozzetti M, Foscolo AM, Betti R. .Margin detection using digital dermatoscopy improves the performace of traditional surgical excsion of basal cell carcinomas oh the head and neck. Dermatol Surg. 2011;37:280-5.

57. Barcaui C. Análise pré-operatória de tumores cutâneos. Surg Cosmet Dermatol. 2011;3:77-9

58. Carducci M, Bozzetti M, De Marco G. Foscolo AM, Betti R. Usefulness of margin detection by digital dermoscopy in the traditional surgical excision of basal cell carcinomas of the headand neck including infiltrative/morpheaform type. J Dermatol. 2012;39:326-30.

59. Caresana G, Giardini R. Dermoscopy-guided surgery in basal cell carcinoma. J Eur Acad Dermatol Venereol. 2010;24:1395-9.

60. American Academy of Dermatology; American College of Mohs Surgery; American Society for Dermatologic Surgery Association; American Society for Mohs Surgery; Ad Hoc Task Force, Connolly SM, et al. AAD/ACMS/ASDA/ASMS 2012 Appropriate use criteria for Mohs Micrographic Surgery: a report of the American Academy of dermatology, American College of Mohs Surgery, American Society for dermatologic Surgery Association, and the American Society for Mohs Surgery. Dermatol Surg. 2012;38:1582-603.

61. Silverman MK, Kopf AW, Grin CM, Bart RS, Levenstein MJ. Recurrence rates of basal cell carcinomas. Part 1: Overview. J Dermatol Surg Oncol. 1991;17:713-8.

62. Rowe DE, Carroll RJ, Day CL Jr. Long-term recurrence rates in previously untreated (primary) basal cell carcinoma: implications for patient follow-up. J Dermatol Surg Oncol. 1989;15:315-28.

63. Hendrix JD Jr, Parlette HL. Duplicitous growth of infiltrative basal cell carcinoma Analysis of clinically undetected tumor extent in a paired case-control sutdy. Dermatol Surg. 1996;22:535-9.

64. Huang CC, Boyce SM. Surgical Margins of excision for basal cell carcinoma and squamous cell carcinoma. Semin Cutan Med Surg. 2004:23:167-73.

65. Betti R, Radaelli G, Crosti C, Ghiozzi S, Moneghini L, Menni S. Margin involvement and clinical pattern of basal cell carcinoma with mixed histology. J Eur Acad Dermatol Venereol. 2012;26:483-7.

66. Roozeboom MH, Arits AH, Nelemans PJ, Kelleners-Smeets NW. Overall treatment success after treatment of primary superficial basal cell carcinoma: a systematic review and meta-analysis of randomized and nonrandomized trials. Br J Dermatol. 2012:167:733-56.

67. Mina MA, Picariello A, Fewkes JL. Superficial Basal Cell Carcinomas of the Head and Neck. Dermatol Surg. 2013:39:1003-8.

68. Roozeboom MH, Mosterd K, Winnepenninckx VJ, Nelemans PJ, KellenersSmeets NW. Agreement between histological subtype on punch biopsy and surgical excision in primary basal cell carcinoma. J Eur Acad Dermatol Venereol. 2013;27:894-8.

69. Wolberink EA, Pasch MC, Zeiler M, van Erp PE, Gerritsen MJ. High discordance between punch biopsy and excision in establishing basal cell carcinoma subtype: analysis of 500 cases. J Eur Acad Dermatol Venereol. 2013;27:985-9.

70. Russell EB, Carrington PR, Smoller BR. Basal cell carcinoma: A comparison of shave biopsy versus punch biopsy techniques in subtype diagnosis. J Am Acad Dermatol. 1999:41:69-71.

71. Haws AL, Rojano R, Tahan SR, Phung TL. Accuracy of biopsy sampling for subtyping basal cell carcinoma. J Am Acad Dermatol. 2012;66:106-11.

72. Mosterd K, Thissen MR, van Marion AM, Nelemans PJ, Lohman BG, Steijlen PM, et al. Correlation between histological findings on punch biopsy specimens and subsequent excision specimens in recurrent BCC. J Am Acad Dermatol. 2011;64:323-7.

73. Messina MCL, Valente NYS, Castro LGM. Is incisional biopsy helpful in the histopathological classification of basal cell carcinoma? An Bras Dermatol. 2006:81:443-8.

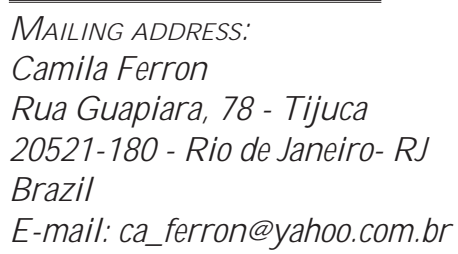

M AILING ADDRESS:

Camila Ferron

Rua Guapiara, 78 - Tijuca

20521-180 - Rio de Janeiro- RJ

E-mail: ca_ferron@yahoo.com.br

How to cite this article: Luz FB, Ferron C, Cardoso GP. Surgical treatment of basal cell carcinoma: an algorithm based on the literature. An Bras Dermatol. 2015; 90(3):377-83. 